\title{
Devaneio e educação
}

Vagner da Silva

Professor adjunto da Universidade Federal de Rondônia

\section{Resumo}

O presente artigo tem por objetivo mostrar que é possível interpretar o pensamento de Rousseau como cíclico, no qual a última etapa, que o encerra e enseja a repetição é o devaneio. Apesar desta circularidade o pensamento de Rousseau não anula história e educação, pois o devaneio possibilita ao indivíduo um contato com a realidade objetiva e também uma fuga dela, fuga que torna o devaneio um marcador temporal e histórico.

Palavras chave: devaneio; educação; repetição.

\begin{abstract}
This article aims to show that it is possible to interpret Rousseau's thought to be cyclical, where the last stage, which encompasses and entails the repetition, is the daydreaming. Despite this circularity the thought of Rousseau does not destroy history and education, because the daydream enables someone to have a contact with objective reality and also an escape from it, scape that turns daydreaming into a temporal and historical marker.
\end{abstract}

Key words: daydreaming; education; repetition. 
onjuntamente a Kant e a Cassirer $^{1}$, penso que a filosofia de Rousseau é um todo coerente. Mas ao contrário destes autores não creio que a educação seja o ponto central e/ou agregador do pensamento do filósofo genebrino. Também não creio que a história antropológica ou a política ocupem tal papel.

Rousseau não conseguiu explicitar o eixo em torno do qual seu pensamento gira. $\mathrm{O}$ que queremos fazer é mostrar que é o próprio giro ou a ideia de giro que mantém tal agregação. O pensamento de Rousseau é um pensamento cíclico: sua história antropológica e tudo o que nela cabe, a educação, a política e a revolução, descrevem, ao longo das obras do filósofo um ciclo, que se completa na ideia e na prática do que Rousseau chamou de devaneio. Apenas observado de perto o pensamento de Rousseau descreve uma reta, com algum distanciamento teórico pode-se perceber também um pensamento cíclico.

Não queremos com isso afirmar que Rousseau foi um teórico da repetição como o foram Freud e Nietzsche. Rousseau não se deu conta de que inclinava, já ao final da vida, seus conceitos em direção a um movimento cíclico. Para tal compreensão, claro, não se pode tomar nenhum livro de Rousseau isoladamente, deve-se vê-lo como um filósofo de grande complexidade, complexidade constituída por tramas educacionais, linguísticas, históricas, antropológicas, políticas etc. e acima de tudo, tem-se que pensar no conjunto de sua obra.

Neste circulo, a educação pensada como no Emílio, ou seja, como retardamento da ação social, permitindo que o indivíduo mantenha-se natural por mais tempo, essa educação é uma etapa que tenderá sempre a se

1 Conforme Starobinski (1991, p. 42). E também Cassirer (1999): “[...] até uma idade avançada Rousseau não se cansou de defender e afirmar a unidade de sua obra. Para ele, o Contrato social não é uma dissidência daquelas ideias fundamentais que tinha defendido em seus dois escritos sobre as questões do concurso da Academia de Dijon; ao contrário, é a continuação lógica, a realização e o aperfeiçoamento deles”. (p. 54)

Filosofia e Educação - ISSN 1984-9605 - Volume 4, Número 2

Outubro de 2012 - Março de 2013 
repetir, ela não é algo que aconteceu na infância e nunca mais, mas um acontecimento chave no processo cíclico de formação do humano, pois pelo devaneio, como se verá adiante o homem educa e se educa, independente do lugar, tempo e idade.

Para compreender o mecanismo da repetição no pensamento de Rousseau é fundamental que se compreenda antes dois pontos de seu pensamento: sua "filosofia da história" e a relação pessimismo/otimismo/educação, pois a filosofia da história de Rousseau dá sentido amplo a uma educação que passa por fases pessimistas e otimistas até que se feche o ciclo.

\section{1 - História, educação e pessimismo}

A posição de Rousseau quanto à história é ambígua. É mais do que conhecido o apelo de aparência histórica que ele faz quando tenta explicar as origens da espécie humana, fugindo a uma justificativa bíblica e recorrendo a uma origem natural, compreendida historicamente, ou ao menos, compreendida dentro de um processo no qual há transcurso de tempo. Foi assim que o filósofo elaborou sua ideia de que a humanidade, em suas origens era feliz e plena, vivendo em algo que Rousseau chamou de estado de natureza.

Por outro lado em Emílio o filósofo afirmou que o ensino de história, ou geografia, ou metafísica, seria prejudicial ao pleno desenvolvimento de seu aluno ideal, como se vê abaixo:

Por um erro ainda mais ridículo, fazem-nas [as crianças - VS] estudar a história. Imagina-se que a história está a seu alcance por que não passa de uma coleção de fatos. Mas o que se entende pela palavra "fatos"? Crer-se-á que as relações que determinam os fatos históricos sejam tão fáceis de se apreenderem, que as ideias a esse respeito se formem sem dificuldade no espírito das crianças? (Rousseau, 1999, p. 117)

Filosofia e Educação - ISSN 1984-9605 - Volume 4, Número 2

Outubro de 2012 - Março de 2013 
É claro que aqui se trata de uma questão etária e de desenvolvimento da criança, pois o preceptor de Emílio designará a história como conteúdo importante a ser estudado e aprendido, mas apenas quando isso coincidir com o desenvolvimento cognitivo e moral do aluno.

A complexa relação do pensamento de Rousseau com uma filosofia da história é agravada no início do segundo discurso, o Discurso sobre a origem e os fundamentos da desigualdade entre os homens, pois logo ali o autor afirma sobre o estado de natureza:

[...] um estado que não mais existe, que talvez nunca tenha existido, que provavelmente jamais existirá, e sobre o qual se tem, contudo, a necessidade de alcançar noções exatas para bem julgar de nosso estado presente. (Rousseau, 1983, p. 228)

A soma dos excertos faz parecer que Rousseau tem uma relação puramente teorética com a história, tomando-a apenas como suposição que o ajuda a desenvolver suas teorias sobre a formação do homem e suas relações políticas. Todavia o problema é mais complexo. Ansell-Pearson (1991) afirma que Rousseau foi o filósofo político que descobriu a história como o problema central da experiência da existência moderna (p. 4). E o autor continua:

A origem e a tragédia do desespero de Rousseau sobre o destino da civilização é que ele é o primeiro a olhar para a própria história humana, para a totalidade que a humanidade já havia procurado em mundos transcendentais - na providência divina, em um mundo imutável das formas, e assim por diante - mas ele não consegue encontrar na história só o que a história pode dar-lhe, nomeadamente, a redenção e a solução para o enigma que ele propôs. Rousseau se percebe preso na armadilha do tempo. Se não pode haver um caminho de volta, então nossa única esperança de redenção, a nossa única chance de realizar a verdadeira felicidade humana, justiça, igualdade, e harmonia das relações sociais,

Filosofia e Educação - ISSN 1984-9605 - Volume 4, Número 2

Outubro de 2012 - Março de 2013 
encontra-se no futuro. Mas, 'a própria lei do desenvolvimento histórico que mostrou que havia um caminho sem volta no tempo também mostrou o futuro como destrutivo dos valores humanos'. Rousseau, assim, confronta-nos com uma antinomia, a da natureza por um lado, e da sociedade civil, moralidade, razão, e história por outro. (Ibidem, p. 6)

De fato Pearson tem razão ao constatar o enredamento de Rousseau nas malhas da história. Para fugir a uma explicação divinizante ou religiosa da natureza humana o filósofo recorreu à história, ao seu enredo históricoantropológico no qual o homem surge como uma criatura plena e feliz, e vai, pouco a pouco, se degradando, conforme abandona seu isolamento individual e se insere em grupos humanos maiores e mais complexos.

Todavia Pearson não percebe a real importância da história para o pensador Genebrino, e consequentemente a importância dele para a filosofia da história. O historiador francês Marc Bloch definiu a história como o estudo do homem no tempo (1997, p. 55), o pressuposto básico para que se possa estudar o homem no tempo é a ideia de que ele se altera no tempo. Não faria sentido estudar o homem no tempo se ele não se alterasse. Poderíamos então atualizar a definição de Bloch, dizendo que a história é o estudo das alterações do homem no tempo.

Rousseau foi sem dúvida o primeiro filósofo a lidar com a complexa ideia de que o homem se altera no tempo. Na tradição teológica cristã não faz sentido a ideia de mudança humana no tempo: o homem de hoje é o mesmo de dois mil anos atrás, pois a mudança do homem no tempo invalidaria o juízo divino, ponto central da teodiceia cristã, pois a regra que se aplicou aos homens antigos, não poderia ser aplicada aos homens modernos e contemporâneos, e esta variabilidade da regra, imputaria ao seu criador (Deus) também uma variabilidade, ora pois, um juiz sujeito a variações temporais perde o critério básico da ideia cristã de justiça divina: imutabilidade.

Filosofia e Educação - ISSN 1984-9605 - Volume 4, Número 2

Outubro de 2012 - Março de 2013 
Maquiavel passou próximo à descoberta de Rousseau, e talvez dele se possa dizer, que tenha sido verdadeiramente o primeiro filósofo da história. Quando o filósofo florentino opôs virtu e fortuna, ele apelou para forças contrárias, uma tipicamente humana (virtu) e outra (fortuna) alheia à vontade e aos caprichos humanos. A história se faz, ou existe, apenas na medida em que a força humana é capaz de causar mudanças em sua própria condição existencial ou no mundo. Não há história quando o homem é visto como um fantoche em um grande teatro seja esse teatro comandado por deuses, por Deus, ou pelas forças da natureza.

Maquiavel chegou a conceber a possibilidade de que a virtu do príncipe seria capaz de conter a fortuna ou ao menos se aproveitar dela, o que significaria dizer que há no homem uma capacidade puramente humana, capaz de conter ou pelo menos dominar metade daquilo que constitui sua natureza. Para ele o governante deveria ser capaz de ler nos caminhos da fortuna as indicações necessárias às suas atitudes como governante, devendo adaptá-las às variadas exigências da sorte e do acaso, conforme afirma Skinner (1996):

A noção definitiva de quem é um homem de virtu para Maquiavel, e suas palavras finais de aconselhamento ao príncipe, podem ser resumidas dizendo-se que ele aconselha o príncipe a que trate, mais que tudo, de tornar-se homem de "disposição flexível": deve ser capaz de variar sua conduta do bem ao mal, e do mal ao bem, "conforme lhe ditar a fortuna e as circunstâncias" (p. 159).

É possível perceber em Maquiavel certo indício de mudança humana, porém tal mudança ainda é condicionada por um elemento não humano, é condicionada por um elemento divino ou aleatório: a fortuna.

Embora outros filósofos tenham recorrido a ideias de estado de natureza para explicar as sociedades humanas, para eles não se efetiva nenhuma mudança na natureza humana. Este é o caso de Hobbes: no enredo

Filosofia e Educação - ISSN 1984-9605 - Volume 4, Número 2

Outubro de 2012 - Março de 2013 
hobbesiano o homem é naturalmente mal, violento e rapace, e o contrato social apenas impedirá que com a emergência do Leviatã os indivíduos destruam-se uns aos outros em uma guerra de todos contra todos. Todavia, para Hobbes, o homem civil continua sendo a mesma besta selvagem que era o homem natural, porém agora contido. Se em algum momento faltar o Leviatã a bestialidade tornará a imperar.

Quando se acompanha a descrição que Rousseau oferece da história da decadência humana, tem-se uma autêntica alteração do homem no tempo. Se o homem era originalmente livre, e hoje se encontra a ferros, se tudo está bem quando sai das mãos do criador de todas as coisas, e tudo degenera nas mãos dos homens, o que se nota é uma mudança radical da própria natureza humana.

Rousseau foi o primeiro filósofo a acreditar que aquilo que os seres humanos são mais radicalmente pode ser modificado pelos próprios humanos: a natureza humana original é degradada pelos próprios homens, eles conduziram suas vidas à perdição, eles inauguraram a história.

Tendo modificado sua primeira natureza, o homem passa a ter uma segunda natureza, esta artificial. Se a primeira era caracterizada, entre outras coisas, por uma tendência ao isolamento, a segunda natureza humana, a natureza criada pelo próprio homem, passa a ser caracterizada pela sociabilidade.

Embora Rousseau possa ser chamado de criador da história, ou ao menos de primeiro filósofo da história, ele é também, de certo modo, um negador da história, por mais paradoxal que isso possa parecer. Esse paradoxo surge dependendo do modo que se encara sua obra e o papel que a educação tem nessa obra, ou melhor, o local no qual a educação pode ser encontrada, se no período pessimista ou otimista. Isso porque, quando Rousseau é otimista em relação ao destino humano ele nega a história e a educação, quando é, porém, pessimista, os reafirma.

Filosofia e Educação - ISSN 1984-9605 - Volume 4, Número 2

Outubro de 2012 - Março de 2013 
Aqui a educação passa a ser vista como um processo amplo de formação da natureza humana, e não a especificidade da educação do Emílio, que é apenas uma parte desta formação mais ampla.

Em Rousseau educação e história se imbricam, pois a educação vista como formação ampla da natureza humana descreve o processo pelo qual o homem abandonando a natureza e o estado de natureza torna-se um produto de si mesmo. Ou seja, à educação correspondem as etapas de transformação do homem, do abandono de sua natureza primitiva em direção à sua segunda natureza.

Quando Rousseau se mantém otimista em relação à natureza humana, o homem retorna à natureza, porém aperfeiçoado, acabando assim com a história e a educação, pois o que se tem é um processo de repetição, no estado civil, do que havia no estado de natureza, porém ainda mais aperfeiçoado, numa espécie de aufhebung que antecipa Hegel, a natureza se especializa no homem, fechando o ciclo sobre si mesma.

Se, porém, se toma os momentos pessimistas de Rousseau quanto aos destinos humanos, ele parece inequívoco: não há triunfo da natureza, o que foi perdido não pode ser reencontrado, não há retorno ao natural, restando ao homem buscar uma forma de mitigar a própria infelicidade. Aqui se mantém a história e a educação, pois o homem não é um títere da natureza. Todavia este terceiro momento do pensamento do filósofo já prefigura um novo retorno, fechando o ciclo. Este fechamento, porém é paradoxal em relação à história e a educação: ora os mantém ora os anula.

\section{1 - Educação e pessimismo}

Escrevemos em outro lugar ${ }^{2}$ que a educação em Rousseau escondia-se nos momentos pessimistas de sua vida e obra em relação à natureza humana, e

2 SILVA, Vagner. Rousseau: onde encontrar a educação? Filosofia e educação (Online) Revista Digital do Paideia. Volume 3, Número 2, Outubro de 2012 - Março de 2011.

Filosofia e Educação - ISSN 1984-9605 - Volume 4, Número 2

Outubro de 2012 - Março de 2013 
sumia nos momentos de otimismo. Aprofundando os estudos e leituras da obra de Rousseau e de seus comentadores, o que percebemos é que não há, na obra do filósofo genebrino, dois momentos de pessimismo separados por um momento de otimismo, mas um ciclo no qual pessimismo e otimismo se sucedem até o fechamento de um ciclo. O pessimismo que aparece como terceiro e último momento no pensamento de Rousseau é, na verdade, o início da repetição, e já traz em si a abertura para um novo otimismo.

É importante que possamos acompanhar o argumento, que passo a reproduzir de forma resumida, iniciando pelo momento otimista, que data do período de 1757 a 1771, marcado pela elaboração (quase simultânea) e publicação das obras Júlia, ou a Nova Heloísa, expressão máxima do otimismo; Do Contrato Social e Emílio, ou, da Educação obras nas quais este otimismo é retomado em sentido político e educacional.

Podemos descrever este momento otimista como um percurso no qual a natureza expande seus domínios, apresentando o homem social como seu apogeu: neste caso, o homem social é uma realização da natureza e o percurso humano, tem apenas em aparência uma queda (a perda da natureza primitiva), esta perda é ilusória e serve apenas para que o triunfo da natureza seja realçado.

No período otimista o homem vivia originalmente em estado de natureza, e se preocupava apenas consigo próprio e com a satisfação de suas necessidades, era incapaz de praticar o mal, mas também o bem; vivia uma irresponsabilidade moral, porque não conhecia as noções que precedem a moral: eu e outro.

Para Rousseau este homem natural não era cruel, como o homem primitivo de Hobbes, porque carregava em si um sentimento natural, independente da sociedade e do convívio com outros homens naturais, a piedade. Esta piedade natural, porém, não é exaltada, pelo contrário, é vista como insuficiente. $E$ tal insuficiência é justificada pela falta de reflexão, não 
é uma capacidade propriamente humana, pois não é elaborada como uma lei racional que o homem cria para si mesmo está mais próxima de um instinto de perpetuação da espécie, que permite a aproximação entre os indivíduos para formarem os pares fundamentais à reprodução.

Rousseau desenvolve então um enredo complexo, que visa reabilitar a razão após ter atribuído a ela a queda do homem primitivo: o homem inicialmente vive em estado de natureza, estado em que é livre, mas de uma liberdade rudimentar e inferior, porém ele é perfectível e é isso que o leva ao desenvolvimento da razão, fundamental para sua ascensão do estado natural ao estado civil, em que se torna, por fim, um ser moral e atinge o apogeu de toda a natureza.

Starobinski afirma que esta é uma teodiceia na qual todos são inocentados, não há culpados, porque o que há, é apenas a ação da natureza. E a aqueles que ironizavam Rousseau afirmando que ele queria fazer o homem voltar a andar de quatro pernas e comer capim, ele responde em Emílio que "não se deve confundir o que é natural no estado selvagem com o que é natural no estado civil" (Rousseau, 1999, p. 568). É criada assim uma segunda natureza, que nada mais é que a extensão e continuidade da primeira, porém especializada e com necessidades específicas que são reguladas pela razão e pela moral.

A razão é finalmente alçada a condutora da espécie humana, poderse-ia dizer inclusive, que neste momento otimista, o homem social aparece como superior ao homem natural.

Neste enredo, todavia, transparece não a vitória do homem sobre outros homens ou sobre si mesmo, mas a vitória da natureza sobre os homens, fazendo com que eles, suas regras e costumes, sejam apenas instrumentos, no final é a natureza que triunfa. Se a natureza triunfa, não houve educação, e, tudo o que aconteceu não representou uma ação do artifício humano, agindo e modificando o que o homem é, mas sim, a 
natureza determinando, em último grau, aquilo que o humano seria. Em Rousseau, o otimismo quanto ao futuro da natureza humana está, claramente, dissociado da educação, esta, só aparece em seu período pessimista.

Se o otimismo é facilmente demarcado na obra de Rousseau, não se pode dizer o mesmo do pessimismo. Ele aparece mais claramente nos três discursos, em especial no Discurso sobre a origem e os fundamentos da desigualdade entre os homens. Após vem o dito período otimista, seguido por um novo período pessimista, do qual fazem parte todas as obras publicadas após 1771, embora já seja possível percebê-lo em obras anteriores como Cartas Escritas da Montanha, também nas últimas 5 confissões. É muito provável que as censuras e perseguições sofridas no período posterior ao lançamento de Emílio e do Contrato tenham agravado este pessimismo.

O enredo das origens da espécie humana é o mesmo do período otimista, a diferença é que agora não há recuperação, nem da própria humanidade, e muito menos da razão, que resta como a grande responsável pela perda da natureza humana primitiva e de todos os sofrimentos que se seguem.

O que se tem no momento otimista, é uma tentativa de recuperar a razão, que é condenada no momento pessimista. De um modo geral há uma grande semelhança na justificativa da queda, a diferença reside na impossibilidade de retorno ou reencontro da felicidade, presente no momento pessimista: não há uma redenção da natureza pelas vias da razão e do raciocínio. No momento pessimista, a razão não é uma má fase pela qual se tem que passar para se chegar à consciência moral.

Por que a razão neste momento pessimista não mais eleva e conduz à moral? Aqui há uma radical mudança de opinião quanto à razão, se no momento otimista ela liberta o homem, no momento pessimista ela o

Filosofia e Educação - ISSN 1984-9605 - Volume 4, Número 2 Outubro de 2012 - Março de 2013 
escraviza às convenções sociais. Neste pessimismo a liberdade é radicada apenas no estado de natureza, pois somente nele, não estando o homem habituado a depender dos outros, ele é realmente livre e independente. E esta liberdade não é depreciada, como no momento otimista, que a considera uma liberdade inferior, a liberdade dos instintos apenas, mas, sem a consciência moral. Somente aí, com uma liberdade e independência plenas, o homem foi realmente feliz, abandonar este estado foi terrível para ele, como afirma o segundo discurso.

Aqui surge outro ponto que agrava ainda mais o pessimismo de Rousseau: se no momento otimista é a razão que abre caminho para a moral, e no momento pessimista a razão apenas engendra a diferença, a inveja e a exploração através da fundação da propriedade privada, esta moral é inatingível? Neste estágio pessimista a moral é, de fato, para o filósofo, bastante complexa. Ela é atingível, porém não é uma garantia de felicidade, muito pelo contrário. Podemos encontrar o exemplo para esta afirmação na própria vida de Rousseau. Ele encontrou a paz moral, garantia da consciência tranquila, apenas no isolamento, quando se afastou da sociedade e se retirou para o campo, porém essa fuga é ilusória, ela não pode trazer de volta o que já foi perdido, ela não pode colocar o homem novamente no estado de natureza. $\mathrm{O}$ homem moral nestas circunstâncias sofre ainda mais que os maus, pois tem uma dupla origem seu sofrimento: sofre a perseguição, o descaso e ironia dos maus, incapazes de compreenderem sua busca pela paz moral, e sofre também, porque sabe que sua busca é vã, sabe que não pode ser totalmente bom e já não é capaz de ser mau.

Deste modo se encerra a epopeia humana: não é possível retornar a um estado anterior, e todas as tentativas, apenas aumentarão a dor e o sofrimento do indivíduo que perseverar neste intento, a razão não eleva o homem ao reino moral, pelo contrário, cria uma cisão irreparável e angustiosa entre o ser moral e o ser racional.

Filosofia e Educação - ISSN 1984-9605 - Volume 4, Número 2

Outubro de 2012 - Março de 2013 
Apesar do pessimismo apenas aqui há educação, pois só em meio a este pessimismo o homem é de fato ator e construtor de seu próprio destino, por pior que ele seja. Todavia aqui já surge o primeiro lampejo de um novo otimismo: se o homem foi tão forte, a ponto de anular em si a natureza primitiva com a qual surgiu pela primeira vez sobre a terra, é possível que esta mesma força crie para si algo de novo, e que possa lhe assegurar uma nova felicidade.

\section{2 - Caminhada e solidão: o início do giro}

Até aqui temos surpreendido em Rousseau um pensamento linear dividido em dois momentos pessimistas separados por um momento otimista. Essa visão, porém começa a se modificar nos últimos anos de vida do autor, em especial no momento em que refletindo sobre a natureza e vivendo próximo a ela escreve Os devaneios do caminhante solitário. Embora pouco conhecida, esta é uma das obras mais sutis de Rousseau, com reflexões bastante profundas e centradas sobre a natureza humana e as experiências humanas.

A obra não representa propriamente um retorno ao otimismo da primeira fase da filosofia de Rousseau, o que completaria, sem dúvida, um giro, porém ingênuo, uma mera repetição causada, talvez, por alguma revisão da própria obra. Os devaneios é mais complexo do que isso, ele indica um retorno às origens do pensamento do autor, uma tentativa de reconciliação do humano com a natureza, porém a partir da experiência de um único indivíduo, que seria o próprio Rousseau. Como afirma Starobinski:

Para descobrir o homem da natureza e para tornar-se seu historiador, Rousseau não teve que retomar ao começo dos tempos: bastou-lhe pintar a si mesmo e reportar-se à sua própria intimidade, à sua própria natureza, em um movimento a uma só vez passivo e

Filosofia e Educação - ISSN 1984-9605 - Volume 4, Número 2

Outubro de 2012 - Março de 2013 
ativo, buscando-se a si mesmo, abandonando-se ao devaneio. (1991, p. 30)

A lógica é simples embora tenha consequências profundas: se os humanos são igualmente degenerados frente à sua natureza primitiva, o retorno de um homem a essa naturalidade original pode indicar uma possibilidade coletiva de retorno.

Como se viu anteriormente, seja no momento pessimista, seja no momento otimista, a queda humana está sempre associada ao pensamento racional, que leva os homens a se compararem, e tomarem-se ou por superiores ou por inferiores, nascendo daí o egoísmo e desrespeito pelos demais indivíduos, e também a cobiça.

No momento otimista há uma tentativa de anulação deste efeito nocivo e danoso do raciocínio, fazendo com que ele conduza a uma piedade auto refletida, representada nas obras políticas pela obediência à vontade geral e pela obediência às leis que a coletividade, através da vontade geral, dá a si mesma.

Já na educação, a razão, mantida distante, mas aceita como fundamental para a maturidade civil e política, é responsável também por fazer com que o Emílio consiga distinguir entre as vontades e intenções dos demais humanos para consigo e para que possa moderar suas paixões, escolhendo conscientemente o bem. Nos dois casos a reflexibilidade humana é resgatada.

Os Devaneios, porém, não insiste numa tentativa de resgate da racionalidade. Na obra se opta por outra modalidade de pensamento, que permite a introspecção e a análise, mas que não tem as exigências formais da reflexão racional - o devaneio. É o que o autor afirma:

Algumas vezes, pensei com bastante profundidade; mas raramente com prazer, quase sempre contra minha vontade e como à força: o

Filosofia e Educação - ISSN 1984-9605 - Volume 4, Número 2

Outubro de 2012 - Março de 2013 
devaneio me descansa e me diverte, a reflexão me cansa e entristece; pensar foi sempre para mim uma ocupação penosa e sem encanto. Algumas vezes, meus devaneios acabam pela meditação, mas, mais frequentemente, minhas meditações acabam pelo devaneio e durante tais divagações minha alma vagueia e plana no universo sobre as asas da imaginação, em êxtases que ultrapassam qualquer outro gozo. (Rousseau, 1995, p. 92)

O devaneio substitui a reflexão racional, ele permite a introspecção, mas por não possuir as exigências da racionalidade, mantém-se ligado aos sentimentos, em especial os sentimentos que conduzem às experiências da alteridade. Em toda a obra Rousseau identifica no devaneio a possibilidade de um reencontro com uma subjetividade natural que foi perdida, ou ao menos borrada, e sobre a qual se escreveu a subjetividade do homem civil, público, educado por uma sociedade focada em si mesma e que ignora as necessidades do indivíduo.

Este poder do devaneio é ressaltado em outra passagem da mesma obra, que apesar de longa vale a pena pela demonstração do poder do devaneio em criar uma suspensão das coisas do mundo, inclusive da anulação da percepção da temporalidade, característica marcante do homem social, em favor de um desfrute intenso da pura condição de ser:

Tudo vive num fluxo contínuo na terra: nela, nada conserva uma forma constante e definitiva e nossas afeições, que se apegam às coisas exteriores, passam e se transformam necessariamente como elas. Sempre à nossa frente ou atrás de nós, lembram o passado, que não mais existe ou antecipam o futuro que, muitas vezes, não deverá existir: nada há de sólido a que o coração se possa apegar. Assim, na terra, temos apenas um pouco de prazer que passa; quanto à felicidade duradoura, duvido que seja conhecida. Mal existe em nossas mais vivas alegrias, um instante em que o coração possa realmente nos dizer: Quisera que este instante durasse sempre; e como podemos chamar felicidade a um estado fugidio que nos deixa ainda o coração inquieto e vazio, que nos faz lamentar alguma coisa antes ou desejar ainda alguma coisa depois? (Ibidem, p. 76)

Filosofia e Educação - ISSN 1984-9605 - Volume 4, Número 2

Outubro de 2012 - Março de 2013 
Parece que aqui se deparou com um texto clássico do pessimismo de Rousseau, nele tudo está presente: a impossibilidade da felicidade plena, verdadeira e duradoura; a perda dos afetos humanos, transformados pela transitoriedade da vida e pelo passar do tempo. Mas que não se engane, o filósofo está apenas lançando mão de um expediente retórico para sobrevalorizar o que afirmará no parágrafo seguinte:

\begin{abstract}
Mas se há um estado em que a alma encontra um apoio bastante sólido para descansar inteiramente e reunir todo o seu ser, sem precisar lembrar o passado nem avançar para o futuro; em que o tempo nada é para ela, em que o presente dura sempre sem, contudo marcar sua duração e sem nenhum traço de continuidade, sem nenhum outro sentimento de privação nem de alegria, de prazer nem de dor, de desejo nem de temor, a não ser o de nossa existência e em que esse único sentimento possa preenchê-la completamente, enquanto este estado dura, aquele que o vive pode ser chamado feliz, não de uma felicidade imperfeita, pobre e relativa, como a que se encontra nos prazeres da vida, mas de uma felicidade suficiente, perfeita e plena, que não deixa na alma nenhum vazio que sinta a necessidade de preencher. Tal foi o estado em que me encontrei muitas vezes na Ilha de St. Pierre, em meus devaneios solitários, seja deitado em meu barco, que deixava vagar ao sabor da água, seja sentado sobre as margens do lago agitado, seja em outro lugar, à margem de um belo rio ou de um regato a murmurar sobre o cascalho. (Idem)
\end{abstract}

O que se tem aqui não é um reencontro da natureza primitiva, mas uma pausa nas ocupações do mundo, um momento no qual, por meio do devaneio, o indivíduo pode se colocar em um estado de tranquilidade que repete o estado natural. É interessante notar que o devaneio, neste parágrafo, tem capacidade, inclusive, para sustar os efeitos do tempo, fundamental para a estruturação das sociedades, e claro, fundamental para a existência da história, e consequentemente da educação.

O devaneio representa a possibilidade de se pensar a estrutura filosófica de Rousseau como uma repetição, o devaneio permite que o indivíduo, cuja natureza foi perdida, retorne a ela a qualquer momento.

Filosofia e Educação - ISSN 1984-9605 - Volume 4, Número 2

Outubro de 2012 - Março de 2013 
Rousseau não fala mais em um retorno universal ou social ao estado de natureza, mas do advento de uma nova possibilidade: retornar-se, a qualquer momento, não ao estado de natureza, mas à sensação plena que só neste estado de natureza o homem pôde sentir.

Esta repetição que Os devaneios permite entrever muda, necessariamente, o sentido da natureza e do estado de natureza na obra do próprio filósofo, talvez a natureza não seja a physis, nem mesmo o estado primitivo no qual o humano surgiu. Talvez a natureza seja um eixo em torno do qual todas as experiências humanas giram, de modo que nunca, será possível fugir-se dela.

\section{3 - Experiências psicológicas versus experiências sociais}

É importante agora analisar a complexa relação que este giro instaura, ou melhor, analisar como ele se encaixa dentro de um problema fundamental para o pensamento de Rousseau: como uma experiência psicológica e individual pode resolver os problemas humanos, que são tipicamente sociais? Em outros termos: se o homem primitivo era individual e não social, como foi possível que ele se tornasse um ser social? E este giro que o devaneio permite implica de alguma forma, em uma negação da sociedade? Afinal, os devaneios de Rousseau se deram em ambientes isolados...

O que o devaneio oferece é a solução psicológica para um problema que é, no pensamento de Rousseau, tipicamente social, e que pode ser assim compreendido: o homem primitivo, que vivia em estado de natureza não era social, algo então lhe ocorreu, que o tornou um ser sociável, este acontecimento foi funesto, pois desde então a sociabilidade tem trazido ao homem apenas males, o maior deles a capacidade de reflexão, que embora, em alguns casos, permita uma piedade refletida, e socialmente a obediência às leis auto impostas, também, é, muitas vezes, a ferramenta de que o

Filosofia e Educação - ISSN 1984-9605 - Volume 4, Número 2

Outubro de 2012 - Março de 2013 
homem lança mão para perpetrar seus piores crimes. $\mathrm{O}$ devaneio permite ao homem, mesmo em estado social retomar intimamente o contato com essa natureza primitiva perdida, sustar o tempo nestes momentos e desfrutar de uma felicidade verdadeira.

Neste enredo há duas passagens que restam inexplicadas: como o homem primitivo insociável tornou-se sociável? Como o homem civil, consegue, por meio do devaneio, que é uma experiência psicológica de introspecção, resolver em si problemas que são sociais?

A resposta a estes problemas reside na noção de perfectibilidade. A perfectibilidade é o modo único da natureza, evocando uma argumentação espinozana. Quando se analisa a obra de Rousseau, entre sua primeira fase pessimista e o desenvolvimento dos argumentos otimistas, tem-se a impressão clara de que a natureza age, no homem, por meio de uma força que faz com que ele, apesar de tudo, melhore sempre, esta força é a perfectibilidade, que embora perdida no terceiro período, o retorno do pessimismo, volta, fechando o ciclo, a aparecer nas obras finais do filósofo: por meio do devaneio o homem pode encontrar a perfectibilidade em si mesmo.

Cassirer sem perceber a circularidade do pensamento de Rousseau justifica a coerência interna de sua obra nos seguintes termos:

[...] O problema de Rousseau, à luz do qual todos os seus escritos podem ser considerados, é assim enunciado: "Como pode o homem civilizado recuperar os benefícios do homem natural, assim inocente e feliz, sem retornar ao estado de natureza, sem renunciar às vantagens do estado social?". Os Discursos iniciais são, assim, protestos contra todas as sociedades até então existentes, cujos males eles expõem; o Emílio e a Nova Heloísa apontam o caminho para a reforma do indivíduo nas esferas da moralidade pessoal, das relações familiares e da educação; os escritos políticos posteriores sublinham o tipo de sociedade na qual o homem bom pode viver apropriadamente. (Cassirer, 1999, p. 23).

Filosofia e Educação - ISSN 1984-9605 - Volume 4, Número 2

Outubro de 2012 - Março de 2013 
Embora ignorando o segundo período pessimista de Rousseau, e, por isso, correndo o risco de incorrer em uma interpretação insuficiente da compreensão do filósofo genebrino sobre a natureza humana, Cassirer acerta quando percebe um continuum entre as obras de Rousseau, e mais importante ainda, uma continuidade na compreensão da natureza humana. Essa continuidade é assegurada pela perfectibilidade, é ela que age no humano desde o início, forçando cada indivíduo às transformações pelas quais ele passará.

Claro que a perfectibilidade não age como um destino inexorável. Ela apenas conduz os indivíduos às experiências chaves que promoverão suas transformações. Deste modo, o homem que inicialmente encontrava-se isolado, e era um ser insociável, foi conduzido, pela perfectibilidade, às experiências da carência, que fizeram com que nele fosse despertada a necessidade do outro: sua fraqueza individual não é um limitador, posto que, embora frágil individualmente, suas paixões e vontades também são bastante limitadas, havendo um equilíbrio entre ambas.

A perfectibilidade se manifesta na forma de uma proto piedade, uma piedade ainda irrefletida, que desperta no indivíduo como que uma curiosidade pelo outro, forçando a aproximação. Segundo Starobinski (1991):

[...] Sem que seja necessário invocar a intervenção sobrenatural de um demônio tentador e de uma Eva tentada, a origem de nossa decadência é explicável por razões bem humanas. Porque o homem é perfectível, não cessou de acrescentar suas invenções aos dons da natureza. E desde então a história universal, embaraçada pelo peso continuamente crescente de nossos artifícios e de nosso orgulho, adquire o andamento de uma queda acelerada na corrupção: abrimos os olhos com horror para um mundo de máscaras e de ilusões mortais, e nada assegura ao observador (ou ao acusador) de que ele próprio seja poupado pela doença universal.

Filosofia e Educação - ISSN 1984-9605 - Volume 4, Número 2

Outubro de 2012 - Março de 2013 
O drama da queda não antecede, portanto, a existência terrestre; Rousseau transporta o mito religioso para a própria história; divide-a em duas eras: uma, tempo estável da inocência, reino tranquilo da pura natureza; a outra, história em devir, atividade culpada, negação da natureza pelo homem. (p. 23-4. Destaque nosso)

A relação perfectibilidade/corrupção reflete apenas uma etapa do processo. Pois é a queda que permite ao indivíduo um novo levantar-se, para em seguida cair novamente, até o momento em que o devaneio permita, em meio a queda, e fechando o círculo, uma evocação continua da pureza perdida.

Pela perfectibilidade, então, o homem abandonou o estado de natureza, tornou-se uma criatura sociável e civil, perdeu sua felicidade primitiva, mas construiu para si outra felicidade, artificial, refletida, racional, insuficiente. Todavia, a perfectibilidade não se deteve, acossando o homem por todos os lados o obriga a perceber a precariedade de sua condição, forçando-o a novos passos, a novas descobertas. A perfectibilidade agiu e age sempre na espécie humana como afirma Rousseau (1983):

Mas, ainda quando as dificuldades que cercam todas essas questões deixassem por um instante de causar discussão sobre diferença entre o homem e o animal, haveria uma outra qualidade muito específica que os distinguiria e a respeito da qual não pode haver contestação - é a faculdade de aperfeiçoar-se, faculdade que, com o auxílio das circunstâncias, desenvolve sucessivamente todas as outras e se encontra, entre nós, tanto na espécie quanto no indivíduo; o animal, pelo contrário, ao fim de alguns meses, é o que será por toda a vida, e sua espécie, no fim de milhares de anos, o que era no primeiro ano desses milhares (p. 243)

Claro que a sociedade na qual viveu Rousseau não podia ser comparada às modernas sociedades burguesas, que veem em suas auto realizações o próprio sentido da natureza e da existência, todavia, aquela 
decadente sociedade aristocrática, não era capaz ainda de perceber a historicidade do mundo e da própria sociedade, via-se como algo estável e inabalável. A perfectibilidade agiu, então, de modo a causar transtornos suficientes para que os indivíduos se movessem, por isso Rousseau, o primeiro a perceber estes movimentos da perfectibilidade pode ser chamado de filósofo da revolução, essa revolução é primeiramente humana, e só depois disso assume características políticas.

\section{1 - A educação pelo devaneio}

Se o ser humano é perfectível por que então educa-lo? É necessário compreender que a educação proposta por Rousseau em Emílio não está relacionada com a perfectibilidade humana, pelo contrário, o esforço da educação do Emílio é por retardar a ação da perfectibilidade. O que o preceptor busca é estender, pelo tempo que seja possível, a permanência da criança no estado de natureza, ou seja, travar os movimentos do perfeccionismo que aceleram o desenvolvimento humano.

Porém não importa o quanto o desenvolvimento da criança seja retardado ou acelerado, ela nunca será desnaturada, pois a perfectibilidade é inata nela, logo, independente de para onde avança, sempre avança dentro de limites traçados pela natureza. A educação, porém, levando ao desenvolvimento da razão no momento certo, no fim da adolescência e início da maturidade, permite que o homem perceba os limites da razão, e assim, consiga mais facilmente encontrar no devaneio a possibilidade de abertura de um espaço nos eventos quotidianos que o resgatem da infelicidade.

Todo o Emílio é um grande devaneio, que se inicia já nas primeiras palavras da obra:

Filosofia e Educação - ISSN 1984-9605 - Volume 4, Número 2

Outubro de 2012 - Março de 2013 
[...] Os mais sábios prendem-se ao que aos homens importa saber, sem considerar o que as crianças estão em condições de aprender. Procuram sempre o homem na criança, sem pensar no que ela é antes de ser homem. Eis o estudo a que mais me apliquei, para que, mesmo que meu método fosse quimérico e falso, sempre se pudessem aproveitar minhas observações. (Rousseau, 1999, p. 4. Destaques meus)

Rousseau admite a possibilidade de que seu método seja quimérico e falso, todavia, se suas observações são aproveitáveis, elas o são porque o método, eventualmente quimérico e falso possibilitou tais observações. Falta ao filósofo a palavra, mas o devaneio já é descrito.

$\mathrm{O}$ devaneio educa porque ele permite que em meio à vida civil e suas obrigações políticas, sociais, religiosas etc. o homem crie para si mesmo um espaço de refrigério mental/espiritual, que o desliga não fisicamente, mas mentalmente da sociedade e suas formalidades, permitindo, de modo introspectivo, um encontro com seu eu primitivo, que neste momento do ciclo funde-se, mesmo que por instantes, ao seu eu contemporâneo.

Essa parada introspectiva que o devaneio favorece representa a própria noção de escola e educação dos gregos segundo Mattéi (2002):

O termo skholé, cuja etimologia permanece obscura, significa propriamente a "parada", o "repouso", e, conseqüentemente, o "ócio", essa pausa que permite ao homem não estar mais submetido à urgência da vida quotidiana, e sim levar tempo. $\mathrm{O}$ segundo sentido do termo será a ocupação do homem ocioso, não a ociosidade vazia, mas a plenitude de uma reflexão estudiosa. Apenas relativamente tarde é que a skholé adquirirá o sentido de um estudo regular e constante conduzido numa escola filosófica. Ainda que Platão tenha criado a primeira escola em Atenas, em 387 a.C., segundo o modelo das comunidades pitagóricas da Magna Grécia, ele não utiliza esse termo para designar a Academia ou qualquer outro lugar de estudo. Em contrapartida, dá várias indicações preciosas sobre os vínculos que unem a skholé à Paidéia e à philosophia de um lado, à vida e à agitação dos negócios de outro. É no Teeteto que Sócrates opõe o filósofo que conquistou sua liberdade porque se entrega a um "ócio" real, skholé, ao homem grosseiro e inculto, apaideutos, que recebeu uma formação

Filosofia e Educação - ISSN 1984-9605 - Volume 4, Número 2

Outubro de 2012 - Março de 2013 
de escravo (...). Pela primeira vez Platão liga o ócio, entendido como suspensão dos negócios em curso e, portanto, como uma parada, ao exercício do pensamento que é seu próprio fim para si mesmo. (p. 210).

Aqui podemos finalmente resolver, e de modo bastante simples, o problema da relação experiência psicológica, pessoal e introspectiva como solução para problemas sociais. Primeiramente devemos ter em mente a igualdade básica que Rousseau vê em todos os seres humanos. Se a razão ocasionou a queda de todos os humanos, foi porque todos são iguais, ou iguais em princípios, logo, é possível se pensar, em uma derivação por analogia que o mesmo vale para o devaneio.

Se o devaneio, porém, pode ser a chave para a retomada da felicidade primitiva perdida, o modo como ele agirá em cada indivíduo é diverso, ou seja, o devaneio pode libertar todos os indivíduos das amarras da vida na sociedade civil, mas cada um devaneia de modo próprio, o devaneio age e educa cada um a partir de suas experiências individuais e históricas. Aqui nos deparamos com outra questão que precisa ser respondida: o devaneio, enquanto fechamento do ciclo, não causaria uma anulação histórica? Posto que já vimos que não causa anulação da educação, mas a reforça.

O devaneio não anula a educação e consequentemente a história, pois não se vive no devaneio, o devaneio é um oásis que cada indivíduo pode abrir em seu dia-a-dia, como se entrasse em um paraíso interno próprio, do qual tira forças para se manter na luta de auto aperfeiçoamento da espécie, imposta pela perfectibilidade. É assim que uma experiência pessoal e subjetiva favorece a coletividade: ela fortalece os homens e os indivíduos que já conhecem o devaneio, para que ofereçam pistas para a educação de todos.

Filosofia e Educação - ISSN 1984-9605 - Volume 4, Número 2

Outubro de 2012 - Março de 2013 
Embora os momentos de devaneio sejam ahistóricos, eles estão inseridos em uma vida histórica, e passam a ser marcadores da temporalidade desta vida, como se contássemos nosso tempo e experiências a partir dos devaneios: "tal descoberta se deu dois anos após aquele devaneio". O momento "devaneante" anula, de fato, a temporalidade, mas ao sair dele o indivíduo torna a mergulhar na temporalidade, porém sabendo-a falsa, ou melhor, sabendo-a como não absoluta, como suscetível de burla e escape, e aprende por fim a como burlá-la, e embora continue imerso nela não a crê mais como uma experiência totalizante. Pelo devaneio o homem civil se educa a tal ponto que mesmo vivendo em sociedade pode encontrar em si os prazeres do perdido estado de natureza.

\section{Referências}

ANSELL-PEARSON, Keith. Nietzsche contra Rousseau: Nietzsche's moral and political thought. Nova York: Cambridge University Press, 1991.

BLOCH, Marc. Apologia da História. Rio de Janeiro: Jorge Zahar, 1997.

CASSIRER, Ernst. A Questão de Jean-Jacques Rousseau. Tradução: Erlon José Paschoal, Jézio Gutierre; revisão da tradução: Isabel Maria Loureiro. São Paulo: Editora da Unesp, 1999.

MATTÉI, Jean-François. A Bárbarie Interior: ensaio sobre o i-mundo moderno. Tradução: Isabel M. Loureiro. São Paulo: Unesp, 2002.

MUCHNIK, Pablo. An essay on the principles of Rousseau's anthropolog. Philosopby \& Social Criticism. Vol 26, no 2, pp. 51-77. London: SAGE Publications, 2000.

ROUSSEAU, Jean-Jacques. Do Contrato Social e outros. Tradução: Lourdes Santos Machado. Introduções e notas: Paul Arbousse-Batide e Lourival Gomes Machado. São Paulo: Abril Cultural (Os Pensadores), 1983. . Emílio, ou Da Educação. Tradução: Roberto Leal Ferreira. São Paulo: Martins Fontes, 1999.

- Os Devaneios do Caminhante Solitário. Tradução: Fúlvia Maria Luiza Moretto. Brasília: Editora Universidade de Brasília, 1995.

SKINNER, Quentin. As fundações do pensamento político moderno. Tradução: Renato Janine Ribeiro e Laura Teixeira Motta. São Paulo: Companhia das Letras, 1996.

Filosofia e Educação - ISSN 1984-9605 - Volume 4, Número 2

Outubro de 2012 - Março de 2013 
STAROBINSKI, Jean. A Transparência e o Obstáculo: seguido de sete ensaios sobre Rousseau. Tradução: Maria Lúcia Machado. São Paulo: Companhia das Letras, 1991.

Filosofia e Educação - ISSN 1984-9605 - Volume 4, Número 2

Outubro de 2012 - Março de 2013 